\title{
Relations in the Interorganizational Networks
}

\author{
Zema Tomasz ${ }^{1,2} \&$ Sulich Adam ${ }^{2}$ \\ ${ }^{1}$ Faculty of Electronics, Wroclaw University of Science and Technology, Wroclaw, Poland \\ ${ }^{2}$ Faculty of Management, Computer Science and Finance, Wroclaw University of Economics, Wrocław \\ Poland \\ Correspondence: Sulich Adam, Wroclaw University of Economics, Wrocław, Poland. \\ Email:adam.sulich@ue.wroc.pl
}

Received: June 7, 2019

Accepted: August 16, 2019

Online Published: September 1, 2019

doi: 10.23918/ijsses.v6i1p111

\begin{abstract}
This article is a result of the systematic literature review of relations in the interorganizational networks in the business environment. In recent years, interest in interorganisational networks has been growing among researchers and practitioners. Many authors describing the network define it different due to their specific approach, therefore it has no one specified definition. One of the key advantages of networks in the possibility of collecting and exploring data at interorganizational level of analysis which reflects interdependences between organizations. This theoretical article aims to explain the role of relations in the interorganisational networks, which allow between management in contemporary practices of organizations and value in their development.
\end{abstract}

Keywords: Computer Sciences, Graph Theory, Networks Management, Network Organization

\section{Introduction}

Contemporary organizations face existing, but tough challenges (McKnight, 2014; Strużyna \& StańczykHugiet, 2019). The new business environment imposes new demands on organisations (Lichtarski, 2009). The relations among individual participants of business environment became less transparent both among public and private entities (Austen, 2013a). On the one hand organisations more and more become competitors to each other, especially if they serve to the same customers with the same service or goods (Kulhánek and Sulich, 2018), but on the other hand they are interconnected to each other (Strużyna \& Stańczyk-Hugiet, 2019) because of geographical location, supply chain and distribution channels (Austen, 2013b; Harary, 2018). In the effect of many turbulent situations (Grudziński \& Sulich, 2018; Krupski et al., 2017) coming from business environment organisations try to also cooperate to use more effective possessed actives and to gain more funds (Organa, 2018; Siu \& Wilson, 2007).

This theoretical article aims to explain the role of relations in the interorganisational networks, which allow between management in contemporary practices of organizations and value in their development based on trust (McKnight, 2014; Strategor, 2001; Wirth, 2005). This article is a result of approach that there is a need to develop newer thinking about organisations (Strużyna \& Stańczyk-Hugiet, 2019; Wirth, 2005). Traditional success factors, like organizational size, material and financial resources, or organizational internal structure designed precisely as complex machine, seem to be replaced by the new factors, like speed of activity, flexibility information and innovation (Lichtarski, 2009). This has led to the creation of a newer architectural plan for organizations (Cropper et al., 2009; McKnight, 2014; Niemczyk, 
2006; Siu \& Wilson, 2007). Organizational dynamics, flexibility, adaptiveness and speed to change are well defined concepts in the new characteristics of an organisation (Niemczyk \& Stańczyk-Hugiet, 2014; de Hanika \& Evans, 2006; Thamhain, 2013). The gap in the theory of management is identified in relations among entities which belong to the business ecosystem or interorganizational network (Ajmal \& Koskinen, 2008; Flyvbjerg, 2014; Lichtarski, 2009).

The authors formulate the hypothesis that the more organic structure, the more complex relations surround the organisation i.e. a higher number of various and more sophisticated tools are used in practice. The text is based both on systematic literature studies and the results of case study presented in this paper.

\section{The Graph Theory and Its Implications}

To explain and describe the nature of the relations between organisations the graph theory can be used (Li \& Vitányi, 1992; de Hanika \& Evans, 2006; Siu \& Wilson, 2007; West, 2002). First practical and documented uses of graph theory had a place in Königsberg in $18^{\text {th }}$ century (present city name is Kliningrad in Russian Federation). The graph theory was used to solve problem known under the name of the "Seven Bridges of Königsberg", and it was solved in 1736 by Leonhard Euler (Euler, 1736). The Pregolya river flows through Königsberg and therefore, the city has two islands and area on both side of bank. All this area was connected by seven bridges as shown on Figure 1a (Harary, 2018; West, 2002). The citizens concerned how to cross seven bridges only once and return home. The problem is introduced as simple drawing and graph diagram bellow (Figure 1b).
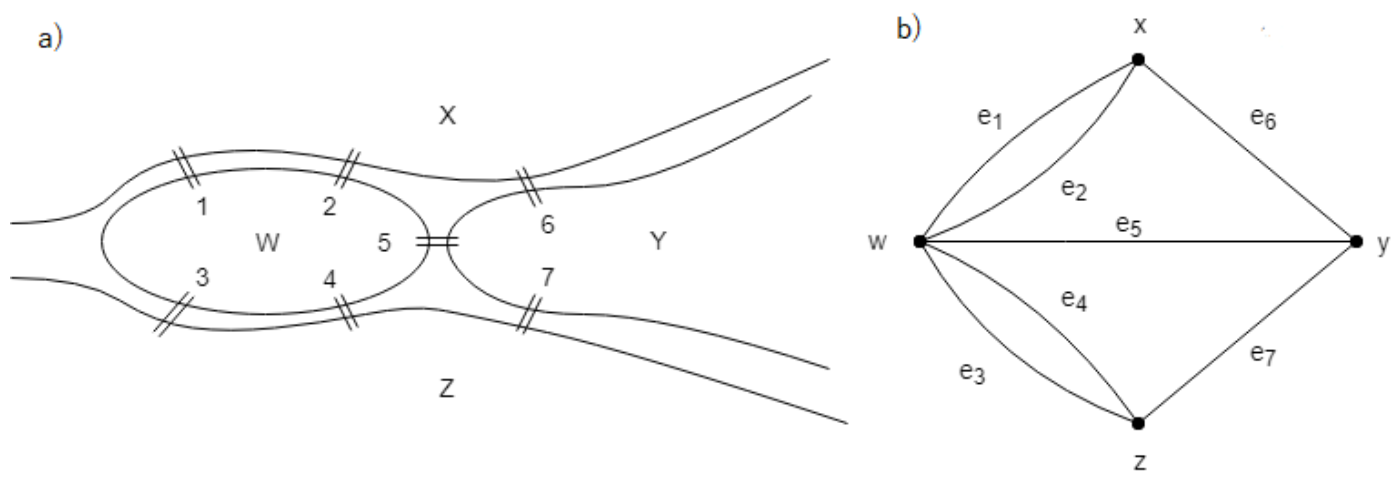

Figure 1: (a) simplified landform with seven bridges; (b) graph model that describes the Königsberg bridge problem. Source: (West, 2002)

It is possible to reduce simple map on the Figure 1a to heavy dots that represents land masses and curved lines mimic bridges (on the right, Figure 1b). The theory of graphs defines such things as vertex set V(G), edge set $\mathrm{E}(\mathrm{G})$, and connection between two vertices by edge defines as endpoints (West, 2002). In the example, the vertex set is $\{\mathrm{x}, \mathrm{y}, \mathrm{z}, \mathrm{w}\}$ and edges $\left\{e_{1}, e_{2}, e_{3}, e_{4}, e_{5}, e_{6}, e_{7}\right\}$. On the drawing we can read where are endpoints. The edges that have same endpoint are called as a loop. It is also possible to distinguish a simple graph that don't have loops or multiple edges. In the simple graph we treat the edge set as a set of unordered pairs of vertices: $\mathrm{e}=\mathrm{uv}$ ( or $\mathrm{e}=\mathrm{vu}$ ) for an edge e with endpoints $\mathrm{u}$ and $\mathrm{v}$. If those endpoints have edge e, they are adjacent and are neighbours. The notation of this relation is $u \leftrightarrow \rightarrow \mathrm{v}$ (u is adjacent to $\mathrm{v}$ ). 
The example of simple graph is cube-like graph (Figure 1b). We can say that graph is finite if vertex set and edge set are in finite set (West, 2002).

Leonard Euler (1736) has shown that this is impossible, and the odd number of bridge outings for each island and the two banks of the river (Euler, 1736, p. 34). He also considered a more general problem, trying to determine the conditions that must be met in order for a coherent graph to be described by a continuous line in such a way that each edge of this graph was only contoured once. Euler showed that this is possible if and only if the number of vertices of the graph in which the odd number of edges meets is 0 or 2 . He also came to the conclusion that to go all the edges of the graph and return to the starting point, he cannot it contain any nodes where an odd number of edges meet (McKnight, 2014).
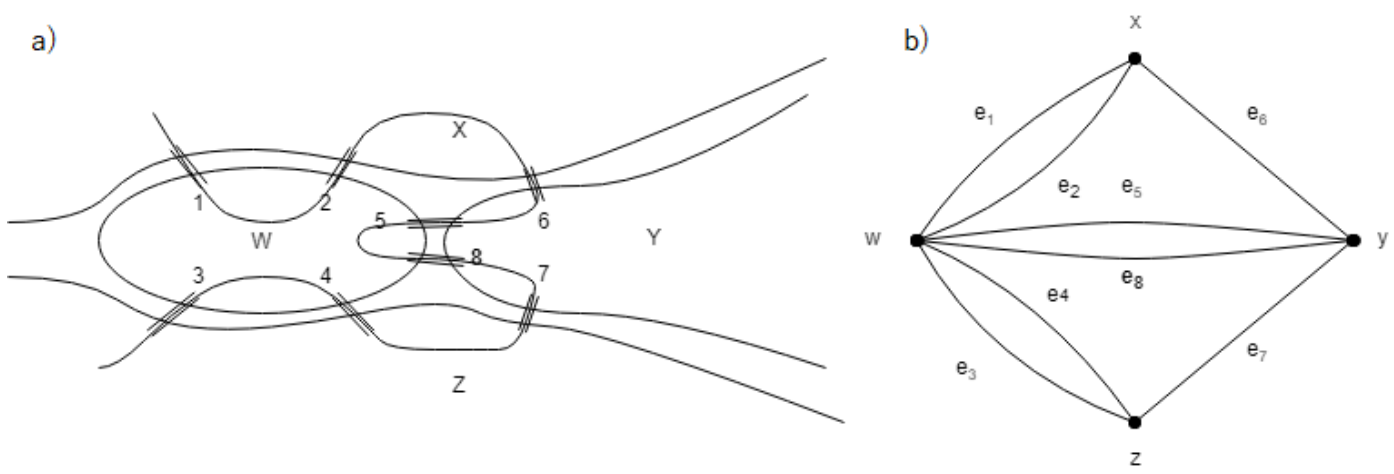

Figure 2: (a) simplified landform with seven bridges with an example solution; (b) modified graph model that describes the Königsberg bridge problem. Source: Own elaboration based on (West, 2002)

Now if it is assumed to theoretically add new bridge in the middle it will reduce number of odd vertices from 4 to 2 and add two even vertices. With such conditions, there is a solution to go over bridges only once. Therefore, there are some well-known network properties (Stańczyk-Hugiet, 2012). Each network has own nodes and edges. If the size of single node rapidly shrink, then rapidly grows number and quality of the relations (edges). If the number of nodes grows asymmetrically, value of the network grows exponentially. This means that, in the networks exist self-reinforcing areas (circles). Each next user (or node) has positive impact on network value, and this causes the synergy effect, because the spiral of benefits attracts other users (Stańczyk-Hugiet, 2012). The interorganizational networks are created to solve problems related to the supply chain (private sector) and social problems (public sector). There is a possibility that networks are created by public and private organisations (Zaheer et al., 1998). Network is a set of programmes and services, which cover wide scope of cooperating organisations, but autonomous - each has its own legal personality (Austen, 2013a; Whetten, 2006). Literature related to the network concept in the public management indicates that there is a possibility to use this idea to protect health, crisis management and provide some social services (Sulich, 2016; Vangen \& Huxham, 2003; West, 2002). Researchers and practitioners are interested especially in addressing three main questions:

1. when the networks really work? (Ajmal \& Koskinen, 2008; Thorelli, 1986); 
2. what are the determinants of networks efficiency? (Mizruchi \& Galaskiewicz, 1993; Niemczyk \& Stańczyk-Hugiet, 2014);

3. what is and how to define the network efficiency? (Austen, 2013a; Baker, 1996; Stańczyk-Hugiet, 2012).

The creation of network relations between organizations aims to increase management efficiency and to improve management of interactions between entities to enhance their cooperation or gain the competitive advantage over the other networks (Thamhain, 2013). As the result if integration of actions among different organisations, their clients can obtain a new quality of the services and products (goods), because of less fragmentarily and better coordination (Sulich \& Zema, 2017a, 2018; Sydow \& Braun, 2018).

In the management science the intergenerational networks may mean the creation of a new form of activity and then it seems to be wise to talk about network organization (structure), or only to conclude agreements or agreements, and then we deal with network cooperation (Niemczyk \& Stańczyk-Hugiet, 2014). The inter-municipal network is created as a result of the election between (Stańczyk-Hugiet, 2012):

- economy of scale or scope,

- to want to reduce costs or obtain new ways of highlighting,

- an innovative fit or just a mimic adaptation to the environment,

- focusing on key competences or acquiring key skills,

- willingness to cooperate or compete,

- the desire for autonomy or relationship.

\section{Inter-organizational Network - Core and Types}

Most generally inter-organizational network is defined as composition of two or more number of entities. They are connected by long term relations (Thorelli, 1986). However, this approach should be restricted, because each organization have structure of open system. This type of organization keeps in more or less stable relationships with the environment (Kulhánek \& Sulich, 2018). Therefore, in the process of defining the concept of the inter-organizational network, a closer description of the characteristics of participants is useful (nodes) and connecting their relations (edges). In the description of the network the most frequently indicators are i.e. voluntary nature of participation, durability connections, cooperation of participants, significant frequency of exchange, the market character of coordination, complementing resources and tasks (co-specialization), possessing complementary resources (Johnson, 2004; Lichtarski \& Bandura, 2016). To sum it up, inter-organizational network is a set of few or a greater number of entities that are independent in terms of organization, legal and economic, coordinated using market mechanisms and relation synergy (or coopetition, if regardless of the cooperation undertaken, they still remain competitors). The network participants determine common goals, interchange information and learn from each other and implement specific activities in the value chain. Activities of network participants are integrated and coordinated with the help of market and social mechanisms. (much less often hierarchical). Furthermore, the network participants have unique resources and complementary skills, which encourages cooperation and development and fosters synergies across the entire network (Lichtarski, 2009; Lichtarski and Bandura, 2016).

The systematic literature review was performed on cross-sections of network analysis in various network researches (Cook, 1977; Cropper et al., 2009; Easton \& Araujo, 1994; Flyvbjerg, 2014; Grudziński \& Sulich, 2018; Häkansson \& Johanson, 1993; Harary, 2018; Klimas, 2016; Maylor et al., 2008; Mizruchi 
\& Galaskiewicz, 1993; Omta et al., 2002; Strategor, 2001; Thamhain, 2013) and were gathered among others by Niemczyk (2006, p. 29) in Table 1. As demonstrated in Table 1 in the majority research results oscillate between relations category.

Table 1: List of analyses (perspectives) of network

\begin{tabular}{|l|l|}
\hline Authors or kind of research perspective & Classifications of research perspectives \\
\hline Häkansson and Johanson (1993, p. 134) & $\begin{array}{l}\text { Actors (subjective) perspective } \\
\text { Relations perspective } \\
\text { Resources perspective }\end{array}$ \\
\hline Häkansson and Johanson (1993, p. 134) & $\begin{array}{l}\text { Network as structure authority } \\
\text { Network as knowledge authority }\end{array}$ \\
\hline According to dynamics of the system theory & $\begin{array}{l}\text { Network as dynamic system } \\
\text { Network as static system }\end{array}$ \\
\hline Easton and Araujo (1994, p. 102) & $\begin{array}{l}\text { Network as relations } \\
\text { Network as position } \\
\text { Network as process }\end{array}$ \\
\hline Strategor (2001, p. 393) & $\begin{array}{l}\text { Perspective of activation } \\
\text { Perspective of combination potential } \\
\text { Perspective of cohesion }\end{array}$ \\
\hline Omta et al. (2002, p. 1) & $\begin{array}{l}\text { Perspective of structure } \\
\text { Perspective of processes } \\
\text { Perspective of evolution (cycle of life) }\end{array}$ \\
\hline $\begin{array}{l}\text { According to the descriptive elements of the } \\
\text { network }\end{array}$ & $\begin{array}{l}\text { Perspective of activities } \\
\text { Perspective of entities } \\
\text { Perspective of relations }\end{array}$ \\
\hline
\end{tabular}

Source: (Stańczyk-Hugiet, 2012, p. 25).

The results emphasize that in the inter-organizational network, the way of functioning is more important than the static arrangement of elements. Thus, authors propose describing network with help of three elements: consistency, combination potential and activation method. Consistency refers to number, diversity and density of relations between network objects. In turn, size and diversity of network vertices determines combination potential. That is, the ability to enter specific network nodes in relations with other network nodes. Activation method describes scope of raising new relations between nodes. In presented view the relations are not although directly characterized neither of their type, however proposed descriptive characteristics with success are used to describe inter-organizational network dynamics.

Interesting proposition of describing inter-organizational relations is concept presented by Mattson (1986, pp. 102-129). Mattson identifies perspectives description relations. Indicated directions of interorganizational relations, they determine the type of relationship that corresponds to them. In any case most of shots types of inter-organizational relations more or less degree is based on (Mattson, 1986) idea (see Figure 3). In any case most of shots types of inter-organizational relations more or less degree is based on L.G Mattsson idea (Stańczyk-Hugiet, 2012, p. 26).

Based on the graph theory it is possible to describe relations from the perspective of subjects of relations (as nodes). Adoption of such a perspective makes it possible to isolate four basic relationships of the organization with various market players. These are vertical reverse relationships (with suppliers), vertical 
frontal relations (with buyers), direct horizontal relationships (with competitors in the industry) and indirect horizontal relationships (with competitors outside the industry). At the same time, relationships can be distinguished in the social, economic and political-administrative spheres that shape the business environment (Stańczyk, 2018; Sulich \& Zema, 2018).

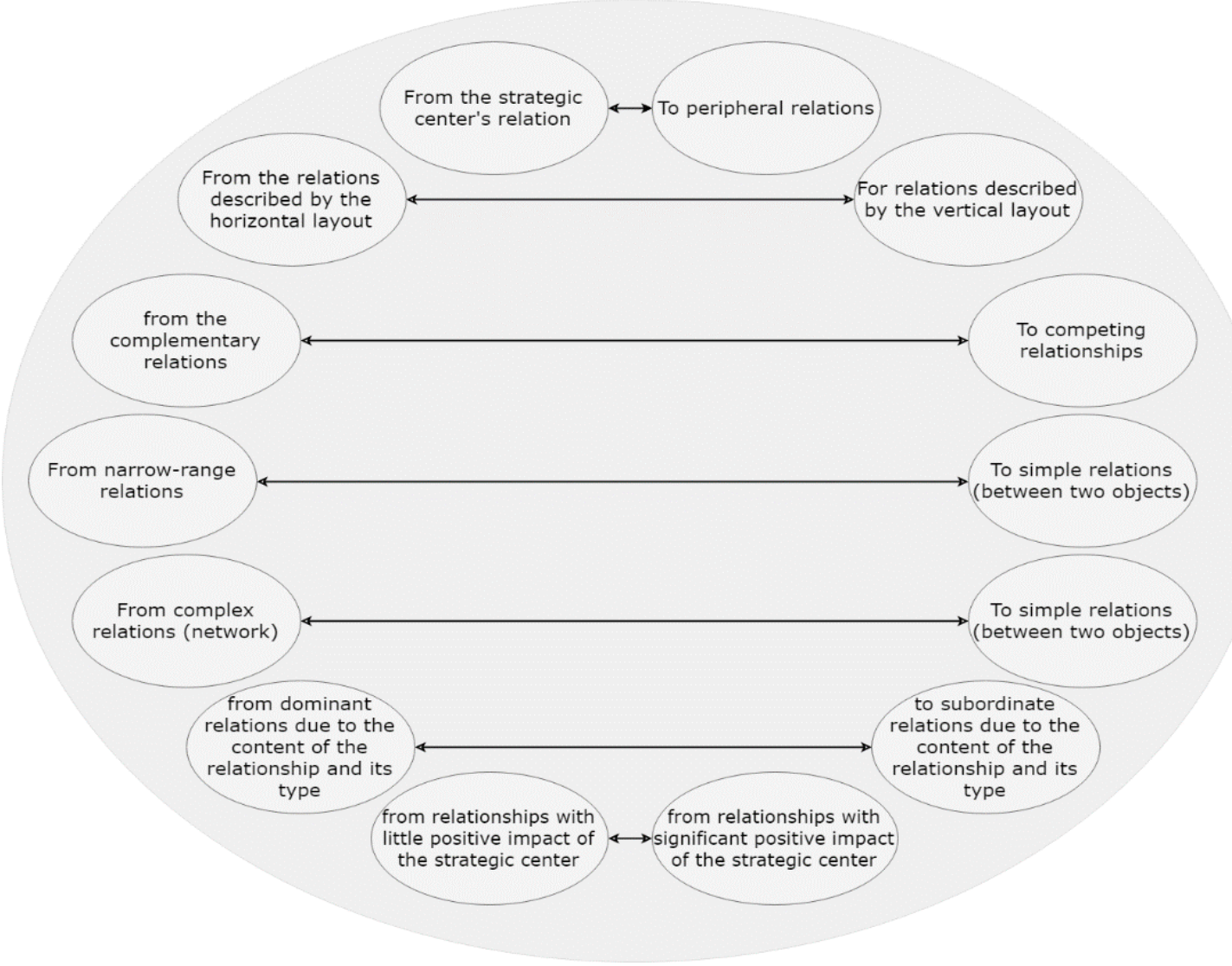

Figure 3: Orientation of relations according to (Mattson, 1986, pp. 102-129)

Source: authors own elaboration based on (Stańczyk-Hugiet, 2012, p. 27).

In many scientific publications that describes inter-organizational network the main goal of establishing relationships is to achieve synergy. The inter-organizational network is the answer of strategic management to the turbulences of the environment, which manifests itself in (Niemczyk, 2006; Niemczyk \& Stańczyk-Hugiet, 2014):

1. extrapolation of trends and any forecasting of the future,

2. the inability to use historical strategies,

3. the situation in the booty, profitability does not necessarily follow growth

4. uncertainty which has become a property of future

5. a surprising character of the surroundings, therefore, the only reasonable solution are inter-organizational networks. 


\section{Trust in the Inter-Organizational Networks}

Trust can be perceived as one of the key factors which can help build and organization's competitive advantage, increase the efficiency and ability to develop (Bieńkowska et al., 2018; Sulich \& Zema, 2017b). Trust is key factor for cooperation, although views on the role and importance of trust in the economy and the organization have evolved with the development of economic thought and the theory of management, from the marginalization of its importance in the process of market exchange, to perceiving the benefits and recognition of trust as an organizational resource (Niemczyk \& Stańczyk-Hugiet, 2014). Trust is a basic component of business life, and it is a social bond (Brickson, 2007; Campbell, 2005). In general terms, it is understood as a multidimensional construct, it is not easily categorized, although the literature provides a variety of attempts to define it (Bieńkowska et al., 2018).

Trust is a willingness of a party to be vulnerable to the actions of another party based on the expectations that the other will perform a particular action important to the trustor, irrespective of the ability to monitor and control that other party (Bieńkowska et al., 2018; Cook, 1977; Cropper et al., 2009). Trust can be defined from the general perspective, as well as in reference to the world of organizations, and the latter context will be the subject of this research (Klimas, 2016). The main field will be intra-organizational trust (the aspects of which include trust towards superiors/managers, trust towards subordinates and trust towards co-workers and according to this approach (Johnson, 2004), trust in understood as the positive expectations individuals have about the intent and behaviours of multiple organizational members based on organizational roles, relationships, experiences, and interdependencies (Bieńkowska et al., 2018).

\section{Types of Relations in the Interorganizational Network}

Determinants of inter-organizational relations are: trust, admissibility of relationships, their diligence and intensity as well as the distribution of power (Brickson, 2007; Li \& Vitányi, 1992; Stańczyk-Hugiet, 2012). Analysing the balance of power between entrepreneurs, one can distinguish between the perspective of degree of accuracy and the degree of equivalence of relations. These two perspectives allow you to hone four forms of relationship due to the power distribution. They are relationships of mutual independence, unequal independence, mutual dependence and an irrelevant dependency (Table 2).

Table 2: Interorganizational relations - perspective of power distribution

\begin{tabular}{|l|c|c|c|}
\cline { 3 - 4 } \multicolumn{2}{c|}{} & \multicolumn{2}{c|}{ relationship strength } \\
\cline { 2 - 4 } \multicolumn{2}{c|}{} & loose relation & tide relation \\
\hline \multirow{2}{*}{$\begin{array}{l}\text { relationship } \\
\text { equivalence }\end{array}$} & equivalence & mutual independence & mutual dependence \\
\cline { 2 - 4 } & inequivalence & unequal independence & inequal dependence \\
\hline
\end{tabular}

Source: (Stańczyk-Hugiet, 2012, p. 29).

In such an identified implementation scheme, one can indicate relations closer to the market idea (relations of intentional independence and inequalities of independence) and relations closer to the hierarchical relationship (dependency relations). This approach brings with its specific consequences regarding the 
legal form of relationships that are the basis for the creation and operation of inter-organizational networks, for example between suppliers and producers (Stańczyk-Hugiet, 2012, p. 29). Relationships of independence and dependence affect the acceleration of development and building a competitive advantage, among others by improving the efficiency (Pham, 2005, pp. 235-266). Dependence relationships in the inter-organizational network mean that participants (entities of such relationships) can obtain higher profits from relationships by reducing costs. On the other hand, relationships of independence bring more benefits when there is no need to maintain many relationships between network partners (Harary, 2018; Sulich \& Zema, 2017b; Wirth, 2005). When products and components are standardized, networks based on independence relationships can have more advantages because they induce innovation and the need to adaptation (Table 3).

Table 3: Independent and dependent relations in the interorganizational networks

\begin{tabular}{|l|l|l|}
\hline & Independent relations & Dependent relations \\
\hline Characteristics & Short-term & Long-term \\
& Distance (loose) & Close (tide) \\
Small size & Small information exchanges \\
Span & $\begin{array}{l}\text { More information exchanges } \\
\text { Complexity } \\
\text { Stabilized by the self-control }\end{array}$ \\
& $\begin{array}{l}\text { Simplicity } \\
\text { Non-stabile and requires direct } \\
\text { management tools }\end{array}$ & \\
\hline $\begin{array}{l}\text { Knowledge development } \\
\text { (perfecting) }\end{array}$ & $\begin{array}{l}\text { More effective in open } \\
\text { knowledge }\end{array}$ & $\begin{array}{l}\text { More effective in classified } \\
\text { knowledge exchange }\end{array}$ \\
\hline
\end{tabular}

Source: (Pham, 2005, p. 12; Stańczyk-Hugiet, 2012, p. 30)

As indicated in the analysis of table 3, the indicated types of relations include coordination mechanisms ranging from low level of coordination and low power asymmetry in relation to market roaming, to a high level of coordination and a large asymmetry of power with respect to hierarchy. Value of the network depends on kind of relation which creates edges in the graph of network. Relations in the network are based on the exchange of certain set of information, sharing resources or human resources migration between organizations that creates network (Stańczyk-Hugiet, 2012; Stańczyk, 2018). Resources in the interorganizational network depends on knowledge and information transfers which are predefined by trust (Bieńkowska et al., 2018; Lichtarski, 2009).

\section{Conclusion}

Considering the challenges in revealing the importance of relations in the interorganizational networks, several distinguished theories come into mind while searching for explanations, such as dialectics, autopoiesis, sensemaking, chaos and evolutionary theories. All these theories focus on the logic of change affected by contradictions, dynamics, indeterminacy, etc; however only the graph theory refer directly to the imperative of persistence and survival in terms of trust and cooperation. Both these aspects provide explanatory mechanisms, that are responsible for the living organism (business entity) to survive or die. Networks relations subject is still waiting for the deep analysis and research. Presented in this paper results 
of existing researches indicates that there is a knowledge gap in this area, which should be subject of further examination.

\section{Acknowledgement}

The project is financed by the Ministry of Science and Higher Education in Poland under the programme "Regional Initiative of Excellence" 2019 - 2022 project number 015/RID/2018/19 total funding amount 10721 040,00 PLN.

\section{References}

Ajmal, M.M. \& Koskinen, K.U. (2008). Knowledge Transfer in Project-Based Organizations: An Organizational Culture Perspective. Project Management Journal, Retrieved from https://doi.org/10.1002/pmj.20031.

Austen, A. (2013a). Koncepcja sieci w zarządzaniu publicznym: pomiar efektywnosci partnerstw lokalnych. Prace Naukowe Uniwersytetu Ekonomicznego We Wrocławiu, 277, 360-366.

Austen, A. (2013b). Między współpracą a rywalizacją w sieciach. Wyniki badań empirycznych. Przedsiębiorczość i Zarządzanie.

Baker, V. (1996). Hypotheses and geomorphological reasoning. The Scientific Nature of Geomorphology; Proceedings of the 27th Binghampaton Symposium in Geomorphology, 2729 September.

Bieńkowska, A., Walecka-Jankowska, K., Zabłocka-Kluczka, A., \& Zimmer, J. (2018). Influence of intra-organizational trust on organizational outcomes. Operations Research and Decisions, 4 , 9-30.

Brickson, S. L. (2007). Organizational identity orientation: The genesis of the role of the firm and distinct forms of social value. Academy of Management Review. Retrieved from https://doi.org/10.5465/AMR.2007.25275679.

Campbell, P.L. (2005). Peirce, Pragmatism, and The Right Way of Thinking. SANDIA REPORT.

Cook, K.S. (1977). Exchange and Power in Networks of Interorganizational Relations. Sociological Quarterly. Retrieved from https://doi.org/10.1111/j.1533-8525.1977.tb02162.x.

Cropper, S., Huxham, C., Ebers, M., \& Ring, P.S. (2009). The Oxford Handbook of Inter-Organizational Relations, The Oxford Handbook of Inter-Organizational Relations. Retrieved from https://doi.org/10.1093/oxfordhb/9780199282944.001.0001.

Easton, G., \& Araujo, L. (1994). Market Exchange, Social Structure and time. European Journal of Marketing, 3(28).

Euler, L. (1736). Solutio problematis ad geometriam situs pertinentis. Comment. Acad. Sci. U. Petrop, 8, $128-140$.

Flyvbjerg, B. (2014). What you should know about megaprojects and why: An overview. Project Management Journal. Retrieved from https://doi.org/10.1002/pmj.21409.

Grudziński, A., \& Sulich, A. (2018). Strategic goals of renewable energy sector", in Sulich, A. and Wodo, W. (Eds.), Proceedings of 16th Students' Science Conference "Science Is Our Universe”, Oficyna Politechniki Wrocławskiej, Boguszów-Górce, pp. 36-44.

Häkansson, H., \& Johanson, J. (1993). The Network as a Governance Structure: Interfirm Cooperation Beyond Markets and Hierarchies", in Grabher, G. (Ed.), The Embeded Firm. The SocioEconomics of Industrial Networks, Routledge, London, p. 134.

Harary, F. (2018). Graph Theory, Graph Theory. Retrieved from https://doi.org/10.1201/9780429493768.

Johnson, R.B. (2004). Mixed methods research: A research paradigm whose time has come. Educational Researcher. Retrieved from https://doi.org/10.3102/0013189X033007014. 
Klimas, P. (2016). Organizational culture and coopetition: An exploratory study of the features, models and role in the Polish Aviation Industry. Industrial Marketing Management. Retrieved from https://doi.org/10.1016/j.indmarman.2015.11.012.

Krupski, R., Piórkowska, K., \& Sus, A. (2017). Organizational endogenous development: The microfoundations, opportunities and real options perspective. Argumenta Oeconomica. Retrieved from https://doi.org/10.15611/aoe.2017.1.03.

Kulhánek, L., \& Sulich, A. (2018). Financial risk in the contemporary environment of enterprises. Zeszyty Naukowe Wyższej Szkoły Humanitas Zarządzanie. Retrieved from https://doi.org/10.5604/01.3001.0012.2038.

Li, M., \& Vitányi, P. (1992). Inductive reasoning and kolmogorov complexity. Journal of Computer and System Sciences. Retrieved from https://doi.org/10.1016/0022-0000(92)90026-F.

Lichtarski, J.M. (2009). Organizational Structure and Knowledge Management. Argumenta Oeconomica, 1(22), 83-101.

Lichtarski, J.M., \& Bandura, P. (2016). W kierunku sieci międzyorganizacyjnej - przykład odnowy strategicznej MY TRAVEL SP. Z O.O. Prace Naukowe Uniwersytetu Ekonomicznego We Wrocławiu, 400, 104-112.

Mattson, L.G. (1986) Indirect Relationships in Industrial Networks: A Conceptual Analysis of their Significance. 3rd IIdustrial Marketing and Purchasing [IMP] International Seminar, IRE, Lyon, France.

Maylor, H., Vidgen, R., \& Carver, S. (2008). Managerial Complexity in Project-Based Operations: A Grounded Model and Its Implications for Practice. Project Management Journal. Retrieved from https://doi.org/10.1002/pmj.20057.

McKnight, W. (2014). Graph Databases. Information Management, Retrieved from https://doi.org/10.1016/b978-0-12-408056-0.00012-6.

Mizruchi, M.S., \& Galaskiewicz, J. (1993). Networks of Interorganizational Relations. Sociological Methods \& Research. Retrieved from https://doi.org/10.1177/0049124193022001003.

Niemczyk, J. (2006). Wyróżniki, Budowa i Zachowania Strategiczne Układów Outsourcingowych, Akademia Ekonomiczna we Wrocławiu, Wrocław.

Niemczyk, J., \& Stańczyk-Hugiet, E. (2014). Cooperative and competitive relationships in high education sector in Poland. Journal of Economics \& Management.

Omta, S., Trienekenes, J., \& Beers, G. (2002). A Research and Management Agenda for Chain and Network Science. Journal of Chain and Network Science, 1.

Organa, M. (2018). Leadership embedded within centralized and decentralized networks: A case study of IT software and services company. Proceedings of the 31st International Business Information Management Association Conference, IBIMA 2018: Innovation Management and Education Excellence through Vision 2020, pp. 4260-4272.

de Hanika, F., \& Evans, W. M. (2006). Interorganizational Relations. Operational Research Quarterly (1970-1977). Retrieved from https://doi.org/10.2307/3008859.

Pham, T. H. (2005). The Competition and Evolution of Business Architecture: The Case of Vietnam's Motorcycle Industry, Impproving Industrial Policy Formulation, The Publishing House of Political Theory, Tokio.

Siu, M. K., \& Wilson, R. J. (2007). Introduction to Graph Theory. The Mathematical Gazette. Retrieved from https://doi.org/10.2307/3620453.

Stańczyk-Hugiet, E. (2012). Charakterystyka relacji, in Niemczyk, J., Stańczyk-Hugiet, E. and Jasiński, B. (Eds.), Sieci Międzyorganizacyjne, Wydawnictwo C.H. Beck, Warszawa, pp. 25-33.

Stańczyk, S. (2018). Tożsamość Ekosystemu Biznesu. Wydawnictwo Uniwersytetu Ekonomicznego we Wrocławiu, Wrocław.

Strategor. (2001). Zarządzanie Firma. Strategie. Struktury. Decyzje. Tożsamosć. Polskie Wydawnictwa Ekonomiczne, Warszawa. 
Strużyna, J., \& Stańczyk-Hugiet, E. (2019). Evolutionary Approaches and Organization and Management Theory (OMT): Common Ground. Evolutionary Selection Processes. Retrieved from https://doi.org/10.1108/978-1-78769-685-320191001.

Sulich, A. (2016). Active labour market policy as a source of legitimacy for governments of Central Europe countries - comparative analysis. World Scientific News, 60, 78-91.

Sulich, A., \& Zema, T. (2017a). Społeczna odpowiedzialność biznesu a zielone miejsca pracy. Marketing i Rynek, 11 (24), 579-591.

Sulich, A., Zema, T. (2017b). Problem zarządzania ryzykiem we współczesnej filozofii techniki”, in Olkiewicz, M., Woźniak, M., Drewniak, M. and Chmura, J. (Eds.), Nauka i Biznes - Wyzwania XXI Wieku. Cz. 2, Wydawnictwo Naukowe Intellect, Waleńczów, pp. 8-21.

Sulich, A., \& Zema, T. (2018). Green jobs, a new measure of public management and sustainable development. European Journal of Environmental Sciences. Retrieved from https://doi.org/10.14712/23361964.2018.10.

Sydow, J., \& Braun, T. (2018). Projects as temporary organizations: An agenda for further theorizing the interorganizational dimension. International Journal of Project Management. Retrieved from https://doi.org/10.1016/j.ijproman.2017.04.012.

Thamhain, H. (2013). Managing risks in complex projects. Project Management Journal. Retrieved from https://doi.org/10.1002/pmj.21325.

Thorelli, H. B. (1986). Networks: Between markets and hierarchies. Strategic Management Journal. Retrieved from https://doi.org/10.1002/smj.4250070105.

Vangen, S., \& Huxham, C. (2003). Nurturing Collaborative Relations: Building Trust in Interorganizational Collaboration. The Journal of Applied Behavioral Science. Retrieved from https://doi.org/10.1177/0021886303039001001.

West, D. B. (2002). Introduction to Graph Theory, second edi., University of Illinois - Urbana, Pearson Education, Sinagopoore.

Whetten, D. A. (2006). Interorganizational Relations: A Review of the Field. The Journal of Higher Education. Retrieved from https://doi.org/10.2307/1981150.

Wirth, U. (2005). Abductive reasoning in Peirce's and Davidson's account of interpretation", Semiotica. Retrieved from https://doi.org/10.1515/semi.2005.2005.153-1-4.199.

Zaheer, A., McEvily, B., \& Perrone, V. (1998). Does Trust Matter? Exploring the Effects of Interorganizational and Interpersonal Trust on Performance. Organization Science. Retrieved from https://doi.org/10.1287/orsc.9.2.141.

* This paper was presented at ICABEP 2019 (International Conference on Accounting, Business, Economics and Politics) Conference in Erbil, Iraq. 